\title{
APPLICATION OF THE LOGISTICS PRINCIPLES FOR THE COMPANY OMEGA, S.R.O. IN CRISIS TIME
}

\author{
Michal Balog \\ TU of Košice, Faculty of Manufacturing Technologies, Department of Manufacturing Management, Bayerova 1, 08001 \\ Prešov, Slovakia, michal.balog@tuke.sk \\ Martin Straka \\ TU of Košice, Faculty BERG, Logistics Institute of Industry and Transport, Park Komenského 14, 04384 Košice,
} Slovakia, martin.straka@tuke.sk

Keywords: crisis, company, analysis, impact of crisis

Abstract: The article is focused on a concrete company and its management practices in crisis state. The content of the article are the characteristics, decomposition, development and consequences of crisis and crisis management through the identification of crisis initiation of crisis management, halting of crisis development and evaluation of crisis management. The article is focused on the possibility of solving crisis that may happen in the company, through avoidance of a crisis implementation of monitoring and controlling the business and to reduce risks and deal with them as soon as possible. The next center of article is evaluation of appropriate methods, which company should focus in case that will into a state of crisis, such as outsourcing, union materials in production, redundancies, restructuring, acquisitions, mergers or sale of the company. There are also evaluated individual company departments by ABC analysis.

\section{Introduction}

Crisis management is applied in practice in different areas, and although a number of practices and methods are identical, there are three different approaches. They are identified mainly in the areas of social policy, the economic and crisis as a result of natural disasters and accidents.

Crisis management in the widest sense begins much earlier than it is possible to identify a crisis and before it gets to the stage of decisive break, even before the crisis occurs. Crisis management is therefore in a permanent process that includes preventive measures leading to a reduction of the destructive effects of the crisis, the establishment of systems for early identification of crisis development and systems for mitigating the impact of the crisis and its rapid successful management.

\subsection{Phases and instruments of a crisis management company}

The duration of the single phases of the crisis varies considerably (Figure 1). For example, a potential crisis if it can be understood as a crisis is a permanent crisis. It is always present in any business enterprise. The second stage is a latent crisis that has just hidden his character and it gives the impression that the company is all well and nothing extraordinary is happening. The problems that arose are common problems, which do not need special attention. There are known cases in which the firm operates at this stage for several years, before swinging into acute crisis phase. Sometimes the transition to this stage is very sudden and fierce. The company has been on the edge between latent and acute phases for a long time, but then just a little momentum, which causes a shift to set imbalance growth in motion.

The third and final phase is usually significantly shorter [1]. Throughout the duration of the crisis, it is necessary to count on its end, and focus its efforts on the future development of the company, have business strategy prepared, which should be focused on the unique production or the services with high added value. If a company comes up with a new business strategy after a crisis, which is based on innovation or technically challenging and unique solutions, then the possibility arises immediately acquire new markets and new customers. Therefore, it is also necessary to think in times of crisis the range of possible changes, changing customer segment, the internal changes in the company etc.

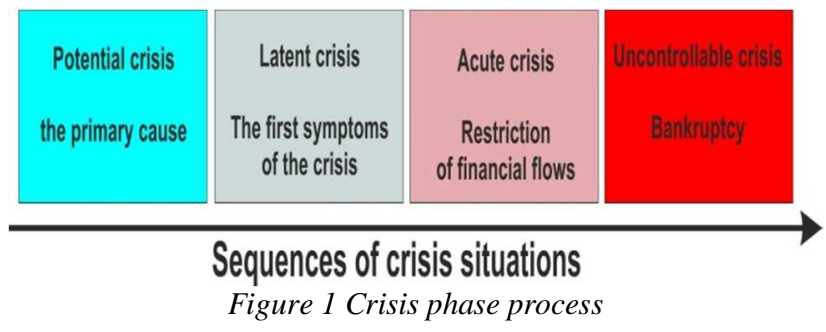

In order to prevent especially the final stages of the crisis, managers can use a variety of instruments such as cash flow business, cost management, monitoring of customer insolvency and so on.

\subsubsection{Ensuring of sufficient company cash flow}

At the time of the crisis, businessmen have limited options to get the money quickly. Banks are more 
cautious and very often refuse to grant credit in the required amount and its long-term clients. A client with a history always has a better chance to succeed than a new client, which runs only with the requirement of the loan. Another option is to obtain cash sale of any real estate firm, of excess inventory, or other unused investment or business property. Traditional options to ensure faster cash flow are factoring, forfaiting, re-leasing and other tools for risk reduction.

\subsubsection{Management of reducing costs (cost cutting)}

If the sales are decreasing, you need to do the restrictions on the cost side as well. This does not just mean the layoffs (even if the salary costs for employees can save up immediately), it is possible to use less drastic ways, such as various forms of reduction of working hours, the usage of unpaid leave and the like. It is necessary to think about the future of the company and keep human resources, if it is possible. Usually there is a significant reduction in the cost of travel, investments in computers and office equipment, fleet renewal and all resources that can be postponed.

In a time of crisis can be relatively easily in firms use a method of centralized purchases of selected raw materials and commodities, which is traditionally recommended for non-manufacturing organizations as one of many economic instruments designed to combat crises [1].

\subsubsection{Monitoring of company customers insolvency}

The course of corporate cash flow is disturbing situation when customers do not pay on time, sometimes because they are not being paid on time, by their customers. The problem of secondary insolvency at the time the crisis is a constant and serious threat. On this occasion, it is necessary to keep in mind that the company has a number of key customers, or some main commodities that form the core of its gross profit. The fall of key customers may cause significant problems in the company. It is therefore necessary to monitor not only cash flow, but also the overall financial situation of key customers. Here is the classic division of customers and suppliers by Pareto principle in place. According to him, is that $20 \%$ of customers create $80 \%$ of total income. It is therefore necessary to take care especially on key customers, but also need to monitor their payment behavior or other signs of the eventual economic problems.

Even during the crisis, it is necessary to count on its end, and concentrate their efforts on the future development of the company, have prepared the business strategy of the company, which should be focused on the unique manufacturing or service with high added value. If after a crisis comes up with a new business strategy, which is based on innovation or technically challenging and unique solutions, then the possibility arises immediately acquire new markets and new customers [2].
Therefore, it is necessary also to think in times of crisis the range of possible changes, changing customer segment, the internal changes in the company etc.

\subsection{Possible solutions of crisis}

At the time of the crisis outbreak, it is important from the perspective of businesses to keep calm and not to succumb the panic. The consequences of the crisis in uncontrolled company are much worse than vice versa, because each business has the potential, which can saved before the crisis and evaluated.

\subsubsection{The crisis prevention}

More important than the solution of crisis from the perspective of the company is that company mustn't get into a crisis. In order to avoid crisis situation, it is appropriate to introduce monitoring of risks, by which to monitor, evaluate and analyze potential risks and hazards that may occur using instruments as:

- monitoring,

- $\quad$ internal audit,

- controlling and so on.

\subsubsection{Appropriate solving methods for company when it finds herself in crisis stage}

In common sense understanding of the concept of restructuring the company to a situation where the business is falling. It is therefore need for a comprehensive, essential change of structure of the company, activities that are going, adjustment or modification of inputs and outputs. The restructuring of the company is a process that tries to solve the serious situation in the life of the company. Restructuring involves serious and substantial interventions in the strategic management of the company and in all departments, whether economic, personal, commercial and industrial [3].

Outsourcing generally refers to securing some of the other activities of the company, outside the organization. Outsourcing is thus a kind of hiring external resources. The purpose of outsourcing is therefore doing activities that the company can provide someone else a cheaper and better to concentrate on the business in which the company incurred. Outsourcing also allows you to temporarily increase the capacity of a company to meet sudden demand.

Management staff reduction could mean a reduction in the firm's financial claims, limiting the negative consequences for the remaining employees, as the case may be, will also create space for the company to restructure and launch new processes. The company should firstly to monitor the early warning signs that may herald the need to reduce the workforce. Such monitoring is sometimes possible to avoid the danger of redundancies.

If the company finds itself in a crisis, the acquisition is for him the possibility of rapid growth with relatively 
little expense, acquisition of intangible assets and easier access to new markets. When a company decides to transpose a joint stock company, then this is done by purchase so-called controlling stake in the company. Acquisition can be achieved by increasing the value of the company, for example, strengthening market position, acquiring know-how and increase revenue through synergistic effect when combining the two companies created a group whose value is greater than the sum of the two companies.

In case the company decides to deal with the crisis through fusion or download companies can have a society benefit from the synergy effect. Synergy benefit based on the consideration that the firm after joining of the two companies has more value than the sum of the individual companies.

\section{Analysis of the company Omega, s.r.o.}

Company OMEGA, s.r.o., doing business in the field of electrical engineering in electrical engineering heavy current segment is stabilized by a clearly defined program of steady production, skilled labor force and perspective production program. OMEGA, Ltd. currently offers a wide range of electrical devices of low and high voltage, forming a comprehensive and complete solution for both low voltage installations residential and commercial space, and industrial spaces, for needs of energy and railways. The company has its own development department, which deals with the upgrading of the main production segments. In his own laboratory company implements basic tests of produced production. The society is also a tool shop that produces molds and tools for newly developed products, but also for re-production.

\subsection{ABC analysis}

Due to the fact that the various products and centers have the same impact on the company profit, it is important to classify the items according to their impact on the observed phenomenon in certain categories. In this case, it is appropriate to use the ABC analysis (Table 1), which helps to divide the items into three categories based on the percentage of the total value of the parameter.

Table 1 Results of ABC analysis

\begin{tabular}{|c|c|c|c|}
\hline $\begin{array}{c}\text { Items } \\
\text { class }\end{array}$ & $\begin{array}{c}\text { Items } \\
\text { numbers }\end{array}$ & $\begin{array}{c}\text { Percentage } \\
\text { stage of items } \\
\text { count }\end{array}$ & $\begin{array}{c}\text { Percentage stage } \\
\text { of turnover } \\
\text { value }\end{array}$ \\
\hline $\mathrm{A}$ & $1,4,5,9$ & $33,33 \%$ & $72,48 \%$ \\
\hline $\mathrm{B}$ & $2,7,8,10,12$ & $41,67 \%$ & $23,04 \%$ \\
\hline $\mathrm{C}$ & $3,6,11$ & $25 \%$ & $4,48 \%$ \\
\hline
\end{tabular}

Items are arranged in categories according to their importance (Figure 2):

- In the category "A" are items that are very important to the organization, they represent great value share of the total annual turnover.
- In the category "B" is less important items, which pays less attention.

- Category "C" grouping items that represent only a small portion of the total value of turnover.

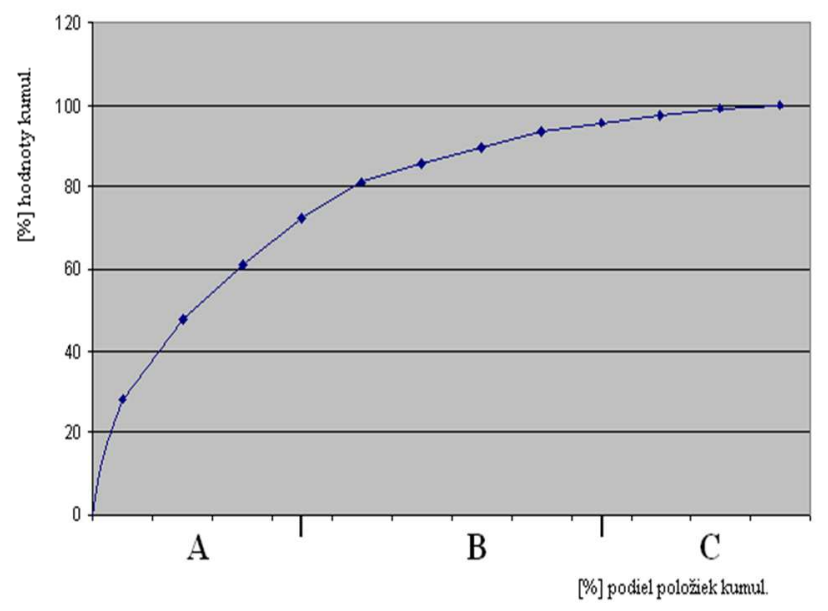

Figure 2 Lorenz curve, ABC analysiss

\section{Design of rationalization measures for increasing the efficiency of company}

If the enterprise wants to be ahead of the competitors, has plenty of money and have not declined over time into a state of crisis, whether effects of the economic and financial crisis, unfavourable legislative standards or other negative phenomena, which may affect the firm, the enterprise should play to their strength sites, to overcome weaknesses by the opportunities and seek to minimize costs.

\subsection{Restructuring the firm}

Experts agree that restructuring may pass by stages. This view is evidenced by the fact that in this case the risk of losing control of the business is clearly smaller than those of the revolutionary transformation company [4]. The practical experience shows that the success of the restructuring can be achieved even when jumping into this process through selected stages. The desired results may be available much sooner than the first approach, although it will need a lot of work. In this case, the risk of losing control of the company is higher. A good practical tool for the design of restructuring becomes called $4 \mathrm{Q}$ matrix restructuring (Figure 3).

Graph shown in Figure 3 can also quantitatively evaluated and based on the result achieved to decide on follow with the changes in terms of production and in terms of corporate strategy. 


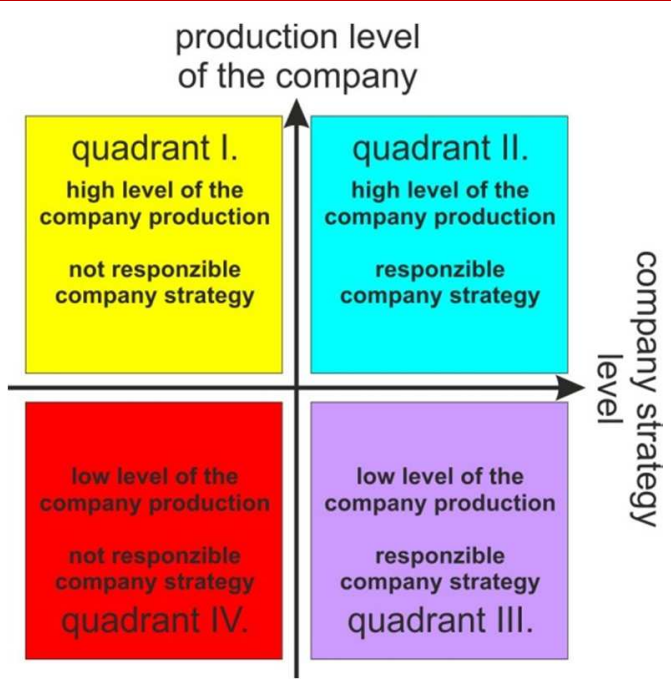

Figure $34 Q$ matrix of restructuring

\section{Quadrant 1}

In the first quadrant, centers are classified class of A B. This group consists of centers that do not yet sufficient profit, but there is opportunity to grow with them. Here again it is necessary to focus attention and business to spend high investment to ensure the operation and upgrade production technology. Here's effort to split the type of transaction that is not in line with the strategic objectives of the company. A clear recommendation is to integrate it into the organization's strategic objectives. It is not worth risking the technical and technological level that is high enough. If it even can not be done, it must be an entity separate economic entity and remain in a highlevel cooperation association with the company, which excelled.

\section{Quadrant 2}

In this quadrant are classified classes of A centers, which have the highest proportion of annual turnover. These centers are the basis of the profitability of the company and they should be given high attention and additional investments. The company should try to maintain this position as long as possible.

The company would construct here "the skeleton" of the company, which is based on a state of crisis. It is clear that from the first quadrant of the distribution tends to transfer or change the type of business in the second quadrant, which still corresponds to the structure of the new company after the restructuring activities.

\section{Quadrant 3}

Quadrants contain centers class of B. Constitute a relatively small share of the profits, but still firm enough to be earning. It is appropriate that the company used the proceeds from that group and used them to finance the first and second groups, which would ensure their longterm operation and profitability. One possible recommendation for this quadrant is the application of outsourcing, which would reduce the cost of production.
A clear plus for a business unit becomes in the case of strategic importance for the company. Because is the most appropriate recommendation transferred upgrading or other activities that will allow pick up the production level, ie transfer them to the second quadrant.

\section{Quadrant 4}

In the fourth quadrant are the centers with the lowest share of the annual turnover. The enterprise should evaluate whether to continue running the group or delete it before being able to focus more on the first three quadrants. There are presented entities and activities that do not meet business strategy, but the company will be adopted if passed restructuring production levels. Best in this case liquidation or separation into a separate legal entity, respectively new economic entity. If you manage to find an investor, then it makes sense to save the selected relations by transforming unprofitable units in the constitutional capital investor. Then you need to decide whether it is better to give an undertaking to the liquidation or sell it to an investor. In this method, it is important to know that the alignment strategy is more important than the current level of the unit or activity.

\subsection{Use of outsourcing}

One suitable means to save costs for the company is to focus on a total or partial outsourcing activity. It is best to use outsourcing to third quadrant matrix restructuring since the centers have a very high share of the income and who would be able to reduce production costs. In addition to reducing the cost of outsourcing has yet another advantage, and that will increase revenue by focusing on the core business [5]. Then the company does not have to deal with problems that others know better resolved. Introducing outsourcing company can gain several advantages:

- The company can focus on the main core business if the company will focus only on their core business and leave other operations to other companies, starts to show much greater flexibility and flexibility in management. This may occur as a result of the higher quality products and services because the company guarding the quality and operation of only one main activity.

- Access to expert solutions - by outsourcing their support activities can gain access to experts and technologies that would otherwise have been difficult for him to reach. Better technology can help improve the quality of production.

- Improving the management - That advantage is closely related with a focus on the core business. By focusing on smaller volume leads to more operational activities, management style and more efficient management and production.

- Reduce costs - is one of the important reasons why the company should introduce outsourcing. Cost reduction can be achieved mainly through economies of scale, which the supplier to achieve greater efficiency by 
providing services and products to more customers. It is also possible to reduce the cost of better know-how when it can be assumed that a company that specializes in the particular focus will be the best and also better technology and experts.

- Time Benefits - handing over certain activities to external suppliers to significantly reduce production cycle time, which is operated by the company. This makes it possible to provide products or services to customers faster.

- Abandonment of an activity for external suppliers to the firm reduces its fixed costs in the form of fewer assets that would otherwise have had to ensure these activities. With the outsourcing of such fixed costs routed out of business and are purchased as intermediate products and services in the form of variable costs. Variable costs are fixed over the advantage that occurs at such time and the amount that they are required to ensure production.

- Increase the volume of production - increase own production can also be achieved through outsourcing, both in the aftermath of the acquisition of free resources for expansion, as well as in the aftermath of the removal of the bottleneck capacity utilization increased supplier.

- Improve cash flow - the sale of fixed assets, the company receives cash, which can be used otherwise.

- Reducing the risk in the long term - even if outsourcing is considered a risky move, paradoxically, it may be a reduced risk, and if the company transfers the risk of possible investments or changes in technology to the supplier.

\subsection{Unification of input materials}

Another form of cost savings for the company in the event of a crisis can be the unification of the starting material in the production of goods. From ABC analysis of firm shows that are least profitable household installation materials, for which the company should focus its attention. In an effort to reduce production costs and more attractive due to its sale, it is necessary to examine the logistical aspects that can support this effort [6]. Unifying the starting material, companies OMEGA, s.r.o. in times of crisis gain several advantages:

- Limit the number of suppliers, resulting in a reduction in acquisition costs, which do not need to buy different raw materials from multiple suppliers, but the company will purchase select suitable raw materials in large quantities from fewer suppliers.

- Reduce unit cost of the product.

- Quantity discount - given that the company will buy a few ingredients in bulk, there is a possibility of quantity discounts that suppliers can provide.

- Reducing the cost of transport.

- Increase competitiveness - if the company buys only one type of raw materials and use them for a greater range of products then consequently can reduce the selling price of products and thereby increase their competitiveness in the market.

\section{Conclusion}

Crisis as part of the life cycle of the firm is not currently the focus of the company's management, because of its connection with the adverse effects. Nevertheless, the crisis can be seen as a sure chance that you can use to streamline company operations, reduce costs and increase its competitiveness. Very important is the early identification of the symptoms of the crisis, analyzing its causes and launching crisis management. The analysis shows that the Omega Company, Ltd., are some of the few centers financially viable in a time of crisis, the company had a closer focus to restrict potential companies reported higher profits, for example, through the unification of materials in the production, manufacture or transferring to outside the manufacturer by outsourcing. If the company is in a crisis situation as the best solution appears to restructure the company, but first and foremost it is important to avoid concentration risks to these situations and avoid all unnecessary company maintained no amount of money. To prevent risk should mainly introduce the best monitoring and controlling for successfully managing the potential risks.

\section{Acknowledgement}

Paper was created within the VEGA grant project No. 1/0036/12 "Methods development and new approaches to design of input, interoperable and output warehouses and their location in mining, metallurgy and building industries".

\section{References}

[1] ZUZÁK, R., KÖNIGOVÁ, M. Krízové řízení podniku. Praha: Grada Publishing. a.s., p. 253, 2009.

[2] SMEJKAL, V., RAIS, K. Ř́zení rizik ve firmách a jiných organizacích. Praha: Grada Publishing, a.s. Grada Publishing a.s., p. 296, 2006.

[3] KISLINGEROVÁ, E. Podnik v časech krize. Praha: Grada Publishing, a.s., p. 208, 2009.

[4] AKULOV, V.B., RUDAKOV, M.N. Teória organizácie, Petrozavodsk. PETRGU, p. 142, 2002.

[5] WITKOWSKI, K.; SANIUK, S.: Aspekt logistyczny zarzadzania infrastruktura komunalna miasta, Logistyka 41(2): p. 589-600, 2011.

[6] KLEPEK, R.; LENORT, R.: Vícekriteriální analýza a klasifikace zásob v hutním a strojírenském odvětví. Hutnické listy. LXIV(6): p. 131-134, 2011.

\section{Review process \\ Single-blind peer reviewed process by two reviewers.}

